\title{
Soil Chemical Quality and Forest Dieback
}

\author{
H. K. S. G. Gunadasa and P. I. Yapa
}

\begin{abstract}
The study was aimed at investigating the effectiveness of recovering degraded soil chemical qualities to mitigate the mysterious forest dieback in a montane forest. Soil amendments with standard compost, montane mycorrhizae, standard compost with montane mycorrhizae, and a control were used as treatments. Syzygium rotundifolium saplings were used as the indicator plant. Soil pH, EC, Soluble soil Pb, Cd and soil organic matter was compared at $0.20 \mathrm{~m}$ soil depth. Foliar samples from "treated" saplings were tested for $\mathrm{Pb}$ and $\mathrm{Cd}$. Contamination of soil and leaves of the saplings with $\mathrm{Pb}(p$ $<0.001)$ and $\mathrm{Cd}(p<0.001)$ was evident. Positive correlations between soil $\mathrm{Pb}$ and $\mathrm{Cd}$ and leaf $\mathrm{Pb}$ and $\mathrm{Cd}$ were observed $(p=0.001)$. Soil amendment with compost and montane mycorrhizae reduced the soluble $\mathrm{Pb}$ content $(p=<0.001)$. Soil amendment with standard compost and montane mycorrhizae was effective in saving the saplings from $\mathrm{Pb}$ and $\mathrm{Cd}$ toxicity $(p<0.001)$.
\end{abstract}

Index Terms-Montane forest, forest dieback, soil chemical properties.

\section{INTRODUCTION}

The montane forest called 'Horton Plain' in Sri Lanka has held genetic stocks from the mountains of Gondwanaland and carries that history even today. The canopy of commonly found cloud forest is dominated by the endemic keena (Calophyllum walkeri) in association with varieties of Myrtacea (Syzygium rotundifolium and S. sclerophyllum) and Lauraceae (Litsea, Cinnamomum and Actinodaphne speciosa). Strobilanthes spp. (Acanthaceae) dominates the undergrowth, except when in competition with dwarf bamboo (Indocalamus and Ochlandra spp.). There are 54 woody species, of which $27(50 \%)$ are endemic to Sri Lanka, $21(39 \%)$ are restricted to the forest of south India and Sri Lanka, and the remaining 6 species $(11 \%)$ are ubiquitous to the forests of south east Asia. Horton Plain is also home to a number of wild relatives of domesticated plants, such as pepper, guava, tobacco and cardamom.

Horton Plains is considered to be the most important catchment area of the country as it is the originating point of the tributaries of three major rivers. These forests remained largely untouched by the 3000-year-old history of human agricultural activity on the island and the hydraulic civilizations that shaped the landscapes of the lowlands left a comprehensive record that attests to this fact. Horton Plains is rich in biodiversity and most of the fauna and flora within the park are endemic while some of them are confined to highlands of the island.

Manuscript received March 5, 2014; revised May 28, 2014.

H. K. S. G. Gunadasa is with Uva Wellassa University, Badulla, Sri Lanka (e-mail: sajanee2010@gmail.com).

P. I. Yapa is with Sabaragamuwa University, Belihuloya, Sri Lanka (e-mail: piyapa39@co.uk).
It has been observed that trees belonging to different size and age classes within this type of forest have been dying due to a yet unknown factor. This phenomenon was first observed in the Horton Plains National Park. The earliest reports of a significant level of dieback in the forest were by [1] and [2] who suggested that this condition may have an earlier origin. However, the dying of the forest was later observed in several other areas including the Hakgala montane forest in Sri Lanka. The cause of dieback is, however, still very poorly understood.

Assessments with the help of recent satellite images, combined with ground surveys, revealed that about 654 ha, equivalent to $24.5 \%$ of the forest in the park has been subjected to dieback [3]. In Thotupolakanda and Kirigalpotta areas, dieback is more severe with over $75 \%$ of the canopy trees dead and the rest is in a state of degeneration. One of the worst affected trees was Syzygium rotundifolium followed by Cinnamomum ovalifolium, Neolitsea fuscata, Syzygium revolutum and Calophyllum walkeri [4]. It has also been observed that the seedling establishment and forest regeneration appear to be at a very slow state within this area [3]. The total healthy forest in the park amounts to an approximate 2012 ha. The extent of the damage to the forest from dieback appears to be so severe that the standard structure in the affected areas shows dramatic changes. If dieback were to continue at the current rate, the majority of the large trees will disappear from the forest very soon, converting the forest to a savanna.

Many researchers have been working on identifying the root causes of forest dieback in Horton Plains but have ended up with no significant clues about the causal agents and remedial measures for the dieback. Therefore, this study has been designed to investigate the effect of soil chemical quality on forest dieback in the Horton Plains and the impact of recovering degraded soil chemical quality on mitigating dieback.

\section{Methodology}

Horton Plains National Park was the location of the experiment, the highest plateau of Sri Lanka between altitudes of 1,500 and 2,524m [5]. The geographical location is about $32 \mathrm{~km}$ south of Nuwara Eliya in the Central Highlands of Central Province, 6'47 - 6'50'N, 80' $46^{\prime}-80$ '50'E. The annual rainfall in the region is about 2540 $\mathrm{mm}$ [6], but for Horton Plains, it may exceed $5000 \mathrm{~mm}$ [7]. The mean annual temperature in the Horton plains is $13^{\circ} \mathrm{C}$ and the temperature fluctuations during the dry months, January to March, are higher than at other times. Strong winds at gale scales are common during the south west monsoons period [8]. The red-yellow podzolic (Order Ultisol according to USDA Soil Taxonomy) are characterized by a 
thick, black, organic layer at the surface [6].

Twenty-four permanent plots of $20 \mathrm{~m} \times 20 \mathrm{~m}$ were established in June 2008 to represent an affected area in the Horton Plain National Park. Randomized Complete Block Design (RCBD) was used with six replications. Plot locations were selected to cover a $21-40 \%$ dieback of trees and to maintain soil and topography as constant as possible. The area is generally exposed to the wind since it has been reported that wind accelerates dieback [3]. A sketch of the area and the experimental plots mapped using GPS (Global Positioning System) points with $20 \mathrm{~cm}$ accuracy.

Canopy health was assessed using a map published by [3] Assessment of the health of the trees were assessed using characteristics like crown dieback, stem damage, bark damage, defoliation and so on. Seedlings of Syzygium rotundifolium were used for the regeneration of dieback areas. Five saplings of Syzygium rotundifolium (approximately $1 \mathrm{~m}$ in height and $1.5 \mathrm{~cm}$ in Diameter of Breast Height (DBH)) were randomly selected from each sampling plot. The most important reason for the selection of the tree species Syzygium rotundifolium was due to the fact that of all species that have been affected, this specie was the worst affected.

Three soil amendments plus a control, were used for the study. They were Compost (2 kg per sapling), Montane mycorrhizae (2 $\mathrm{kg}$ of topsoil form healthy forest area per sapling), Compost and montane mycorrhizae ( $2 \mathrm{~kg}$ of topsoil from healthy forest area and $2 \mathrm{~kg}$ of compost) and Control (no any application). Well-prepared standard (certified) compost was used at a rate of $2 \mathrm{~kg}$ per sapling on the selected plants in each plot. The compost was carefully mixed with the soil at the base of the Syzygium rotundifolium saplings (50cm away from the stem base and incorporated to soil) to a depth of about $25-30 \mathrm{~cm}$, assuring minimum disturbances to this sensitive natural ecosystem. Natural montane mycorrhizae were collected from healthy areas in the Horton Plains and used at a rate of $2 \mathrm{~kg}$ per sapling on the selected plants in each plot $(50 \mathrm{~cm}$ away from the stem) and incorporated in to the soil with minimum disturbance.

A comparison of key soil chemical properties was done for the selected area with $21 \%$ to $40 \%$ dieback severity. The soil samples were collected from a depth of $20 \mathrm{~cm}$, maintaining an approximate distance of $30-50 \mathrm{~cm}$ from the selected saplings. Soil sampling was done on four different stages within the experimental period. The soil samples were analyzed for $\mathrm{pH}$ [9] and EC (Electrical Conductivity) [10]. Determination of toxic elements of soil $\mathrm{Pb}$ and $\mathrm{Cd}$, were done by wet ash method [11] and the extracts were analyzed for the above elements by Atomic Absorption Spectrophotometry [12]. In addition, the soil organic matter content was determined using the method of total organic $\mathrm{C}$ by Walkley and Black described by Nelson and Sommers [13]. Toxic elements of foliar samples such as $\mathrm{Pb}$ and $\mathrm{Cd}$ were determined using the wet ash method [11]. Death rate of the chosen saplings was calculated by keeping records about dying plants and dead plants throughout the experimental period and counting the dead saplings after two years of the experimental period. Standard GENSTAT statistical software was used for analysis of variance (ANOVA), t-test and regression analysis of the results.

\section{RESULTS AND DISCUSSION}

The results shown here are based on the work done during the two-year study period in Horton Plains National Park (HPNP). The dieback area selected showed $21-40 \%$ severity. Average values of the soil parameters were used to compare the effect of different treatments. Rainfall, temperature, wind speed and direction data for the area are shown in Table I.

TABLE I: PREVAILED WeATHER CONDITIONS DURING THE STUdy PERIOD (METEOROLOGICAL STATION - NuWARA EliYA - LATITUdE: 6 $58^{\prime} 11$ N,

\begin{tabular}{|c|c|c|c|c|c|c|}
\hline \multirow[b]{2}{*}{$\begin{array}{l}\text { Sampling } \\
\text { Stage }\end{array}$} & \multirow{2}{*}{$\begin{array}{l}\text { Monthly } \\
\text { Rainfall } \\
(\mathrm{mm})\end{array}$} & \multicolumn{3}{|c|}{$\begin{array}{c}\text { Monthly } \\
\text { Temperature }\left({ }^{\circ} \mathrm{C}\right)\end{array}$} & \multicolumn{2}{|c|}{ Wind Data } \\
\hline & & Max & Min & Mean & $\begin{array}{l}\text { Speed } \\
\text { (Knot) }\end{array}$ & $\begin{array}{l}\text { Direction } \\
\left({ }^{\circ}\right) \\
\text { From } \\
\text { North }\end{array}$ \\
\hline Stage 1 & 154.7 & 20.01 & 12.29 & 16.15 & 5.1 & 285 \\
\hline Stage 2 & 258 & 21.17 & 11.42 & 16.29 & 12.2 & 282 \\
\hline Stage 3 & 19.4 & 22.09 & 11.97 & 17.03 & 7.9 & 97 \\
\hline Stage 4 & 283.6 & 20.17 & 13.45 & 16.81 & 11.5 & 275 \\
\hline
\end{tabular}

According to climate data, rainfall at stage 3 was nearly twelve times lower compared to the stages 2 and 4 . Stage 1 is also a wet period but the monthly rainfall is seven times higher than that of Stage 3, the dry period. Not much difference in temperature was observed in all the stages of sampling.

\section{A. Soil pH}

$\mathrm{pH}$ value of the soil points out that the soil in the entire area under investigation in the Horton plains is acidic. Soil acidity appears to be bit higher than normal (typical $\mathrm{pH}$ range of soil $=5-9$ ) [14] though the level of acidity may not be uncommon to montane forests. $\mathrm{pH}$ is significantly different among the treatments only at stage $1(p=0.02)$ and stage 2 $(p=0.025)$ in the $0.20 \mathrm{~m}$ depth (Fig. 1). Values of soil $\mathrm{pH}$ varied between 4.3 and 6.3 and similar results have been obtained by [15]. Successful vegetation of Rhododendron arboretum, one of the few plant species that shows exceptionally higher tolerability to soil acidity, and the disappearance of acid susceptible plant species from the area also provide enough evidence to support the claim that the soil acidification may also be behind the problem of degrading forest vegetation. Acidic $\mathrm{pH}$ conditions are not favorable for the soil inhabiting beneficial microbes as well. Fungi may tolerate the acidic $\mathrm{pH}$ to some extent but bacteria and actinomyceties populations are severely affected by acidic soil $\mathrm{pH}$ [16]. Therefore, $\mathrm{pH}$ results could be used to understand relatively poor microbial activities in the soils of Horton Plains [17]. Soil microbes play a key role in plant nutrition and maintaining soil-plant-water relations [18]. Therefore, the plants growing on soils with poor microbial activity are very often subjected to nutrient and toxicity 
problems. Extreme acidic conditions in the soil even causes direct root damages [19]. Mycorrhizal associations in plant roots which are considered to be a natural survival strategy of forest vegetation are also affected by severe soil acidity [20]. Weakening of mycorrhizae in plant roots will have severe impacts on nutrient absorption by plants. Excessive availability of micro nutrient under acidic $\mathrm{pH}$ might lead to toxicity problems for trees. Acidic $\mathrm{pH}$ also increases the mobility of toxic heavy metals in the soil when compared to those in alkaline soils [21].

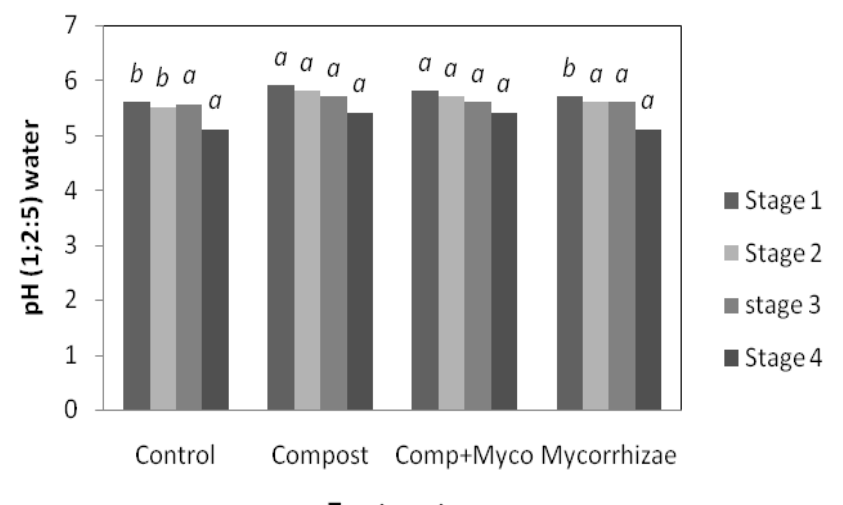

Stage 1 = Rainy season; Stage 2= Rainy season; Stage 3=Dry season; Stage $4=$ Rainy season

Means appear with same letter are not significant at $p<0.05$

Fig. 1. Status of $\mathrm{pH}$ among treatments at four different stages of sampling in $0.2 \mathrm{~m}$ depth.

\section{B. Soil EC}

For purposes of definition, saline soils are those which have an electrical conductivity (EC) of the saturation soil extract of $>4000 \mu \mathrm{s} / \mathrm{cm}$ at $25^{\circ} \mathrm{C}$ [22]. It is generally accepted that soils with EC in the range of $0.0-2000 \mu \mathrm{s} / \mathrm{cm}$ will not present any problem to the germination and growth of majority of forest trees and the previous studies indicated that the extractable quantities of soil $\mathrm{P}$ are little influenced by raising the salinity levels of soils [22]. However, EC values of the soil in the study area indicate that the soil is non-saline (Fig. 2). It is expected that with excessively high rainfall in the area (annual rainfall $=>2000 \mathrm{~mm}$ ), salinity development cannot be expected in the Horton Plains. EC is also significantly different among the treatments at all 4 stages of sampling $(p=0.04),(p=0.042),(p=0.035)$ and $(p=0.041)$.

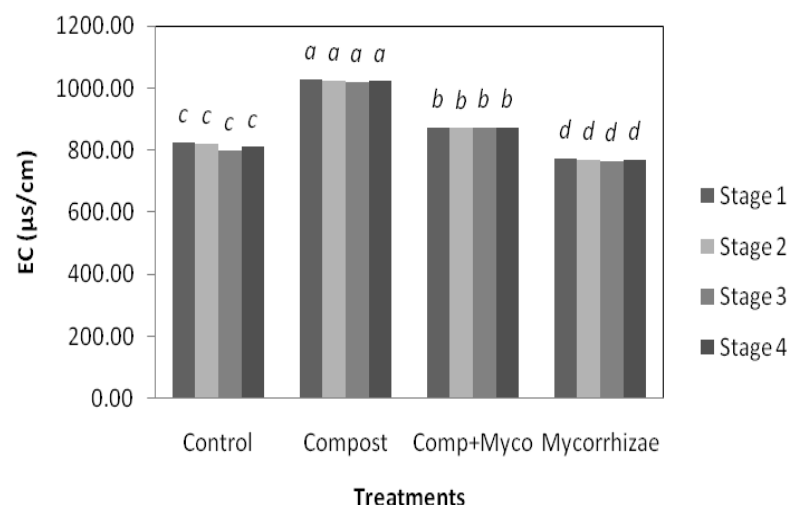

Stage $1=$ Rainy season $;$ Stage $2=$ Rainy season ;Stage 3=Dry season ; Stage $4=$ Rainy season

Means appear with same letter are not significant at $p<0.05$

Fig. 2. Status of EC $(\mu \mathrm{s} / \mathrm{cm})$ among treatments at four different stages of sampling $(0.2 \mathrm{~m}$ depth $)$

\section{Heavy Metals in Soil ( $\mathrm{Pb}$ and $\mathrm{Cd})$}

The level of soil $\mathrm{Pb}$ and $\mathrm{Cd}$ has gone up to 106 and 7.29 ppm respectively. The maximum allowable limit of $\mathrm{Pb}$ is 100 ppm while it is 3ppm for $\mathrm{Cd}$ under tropical moist evergreen forest ecosystems [23]. Even the smallest amount of both $\mathrm{Pb}$ and Cd may impose severe damages on plant's metabolism leading to dieback [24]. Results from both soil and foliar analysis clearly indicated contamination of soil and vegetation from these two trace elements in Horton Plains.

Treatments used for the study have significantly influenced the soil $\mathrm{Pb}$ in $0.20 \mathrm{~m}$ depth at sampling stages 1 $(p=0.01), 2(p=0.004)$ and $3(p=0.004)$ but there was no significant influence detected at stage-4 $(p=0.79)$ (Fig. 3). The highest $\mathrm{Pb}$ content was detected in the control Treatments significantly affected soil Cd at stage- $1(p=0.04)$ and stage-3 $(p=0.042)$ though the highest Cd level in the soil was observed in the control (Fig. 4) at $0.20 \mathrm{~m}$ depth.

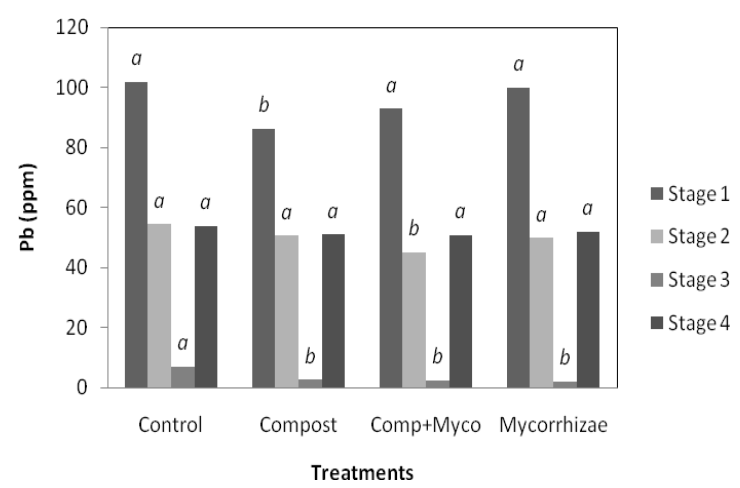

Stage 1= Rainy season; Stage 2= Rainy season; $3=$ Dry season; Stage 4= Rainy season

Means appear with same letter are not significant at $p<0.05$

Fig. 3. Status of $\mathrm{Pb}$ among treatments at four different stages of sampling in $0.2 \mathrm{~m}$ depth.

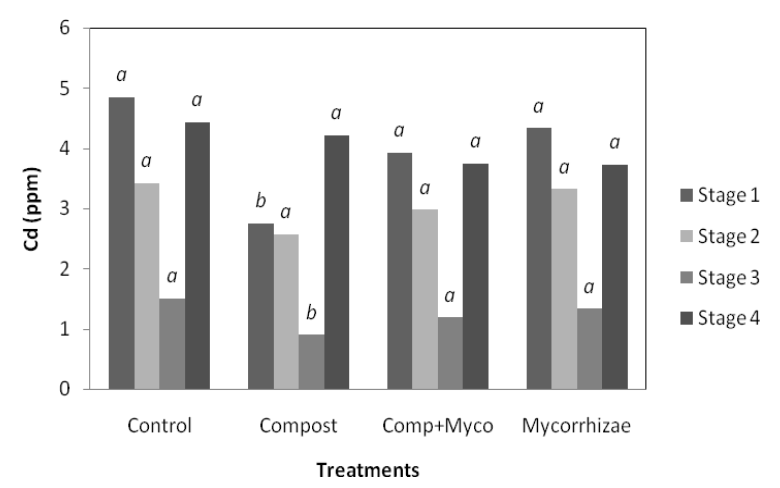

Stage $1=$ Rainy season; Stage $2=$ Rainy season; $3=$ Dry season; Stage $4=$ Rainy season

Means appear with same letter are not significant at $p<0.05$ Fig. 4. Status of $\mathrm{Cd}$ among treatments at four different stages of sampling in $0.2 \mathrm{~m}$ depth.

The main source of $\mathrm{Pb}$ and $\mathrm{Cd}$ to the soils of Horton Plains must be the rain for several reasons. For examples, external addition of soil amendments are not taken place within this well-protected reserve and also the underlying bed rock mainly consists of Khondalite and Charnokites groups which are not considered to be rich with both $\mathrm{Pb}$ and $\mathrm{Cd}$ [25]. Status of air pollution in Kandy, a city that is less than $50 \mathrm{~km}$ away from Horton Plains has been documented [26]. Therefore, during rainy period, continuous addition of $\mathrm{Pb}$ and $\mathrm{Cd}$ to the soil with rain is expected. The soil samples collected during 
the rainy periods were all found in moist condition with rain water soaked into the soil. Air-drying the samples only removes water from the samples leaving $\mathrm{Pb}$ and $\mathrm{Cd}$ behind. Hence, the laboratory analysis would have reflected these metals in higher concentrations for the soil samples collected during rainy periods.

Harmful levels of both $\mathrm{Pb}$ and $\mathrm{Cd}$ in the soil have declined noticeably during the dry period and the decline was significant for both $\mathrm{Pb}(p=0.001)$ and $\mathrm{Cd}(p=0.001)$. A fraction of those elements may leach out from the top soil while another fraction may be absorbed by the vegetation. Results from foliar analysis indicated the entry of $\mathrm{Pb}$ and $\mathrm{Cd}$ into the plant bodies (see Table II). When the levels of $\mathrm{Pb}$ and $\mathrm{Cd}$ in the soil during the dry period are considered, plots treated with mycorrhizae showed lower values when compared to the values observed in the other plots. Even though this decline is not statistically significant under $\alpha$ level 0.05 , the results cannot be ignored. Mycorrhizae significantly increase the absorption of various elements from the soil including heavy metals such as $\mathrm{Pb}$ and $\mathrm{Cd}$ [27]. Therefore, it could be assumed that mycorrhizae are responsible for the reduction of $\mathrm{Pb}$ and $\mathrm{Cd}$ in the soil treated with mycorrhizae.

Results clearly indicated the influence of rain on the contamination of soil with $\mathrm{Pb}$ and $\mathrm{Cd}$ in Horton Plains while heavy motor traffic may be the main cause for the atmospheric pollution from those elements. Kandy has been identified as the worst polluted city in Sri Lanka in terms of heavy motor traffic and resultant vehicle emissions [28]. Burning diesel, gasoline and lubricants releases $\mathrm{Pb}$ and $\mathrm{Cd}$ to the atmosphere. Additionally, the friction by brake pads, clutch liners and tires release these elements to the atmosphere. Strong monsoon winds seem to be the most possible transportation source of $\mathrm{Pb}$ and $\mathrm{Cd}$ from the polluted south western part of the country and following pioneer studies, $\mathrm{Pb}$ and $\mathrm{Cd}$ are subjected to long-range atmospheric transportation to a greater extent [29] where $\mathrm{Pb}$ can be transported for a distance greater than $120 \mathrm{~km}$ [30]. Past studies reported that forest soils exceeding $1800 \mathrm{~m}$ elevation were contaminated with higher levels of $\mathrm{Pb}$ and the atmospheric origin of the excess soil $\mathrm{Pb}$ was confirmed by high $\mathrm{Pb}$ levels in precipitation [31]. Moreover, with increasing visitors to the Horton Plains, motor traffic within Horton Plains itself has increased. Therefore, contamination of atmosphere may have been increased to an alarming level so that it is very unlikely the rain falling onto the area is free from $\mathrm{Pb}$ and $\mathrm{Cd}$. Soil microorganisms play a vital role in maintaining overall soil quality. They have been proved to be effective in detoxifying pollutants in the soil that include heavy metals such as $\mathrm{Pb}$ and $\mathrm{Cd}$. Additionally, beneficial soil microbes provide protection for the plants from pathogens, help with nutrient cycling and providing consolation for plants during stressful conditions such as drought [32]. Soil microbes, on the other hand, maintain extremely useful symbiotic associations with the forest vegetations which provide additional advantage for the plants to mine nutrients and water, for example, mycorrhizal association [33]. However, high levels of heavy metals in soils have been shown to decrease populations of soil microorganisms [34].

Contribution of the microbes in humification process during organic material decomposition should also be noted because humic substances formed during the process play a very special role in controlling the effects of organic and inorganic pollutants in the soil [35]. So, the deterioration of the activities of soil microorganisms as a result of the acidity conditions in the soils of Horton Plains may have placed the forest vegetation in a vulnerable state for soil contaminants like $\mathrm{Pb}$ and $\mathrm{Cd}$ (Table II). Acidic $\mathrm{pH}$ conditions also increase the availability of micronutrients in the soil unnecessarily and this situation results in the development of toxic conditions from micronutrients on plants [36].

TABLE II: VARIATION OF PB AND CD IN THE LEAVES FROM DIFFERENT TREATMENTS

\begin{tabular}{|r|l|l|l|l|l|}
\hline & Treatment & Control & Compost & $\begin{array}{l}\text { Comp+ } \\
\text { Myco }\end{array}$ & Mycorrhizae \\
\hline $\begin{array}{r}\mathrm{Pb} \\
(\mathrm{ppm})\end{array}$ & Mean & 4.133 & 2.1 & 4.217 & 4.217 \\
\hline & & $(0.04)$ & $(0.0)$ & $(0.05)$ & $(0.02)$ \\
\hline $\begin{array}{r}\mathrm{Cd} \\
(\mathrm{ppm})\end{array}$ & Mean & 6.467 & 3.267 & 3.6 & 6.183 \\
\hline & & $(0.12)$ & $(0.08)$ & $(0.09)$ & $(0.06)$ \\
\hline
\end{tabular}

Standard error for the respective mean is given within brackets.

\section{Soil Organic Matter}

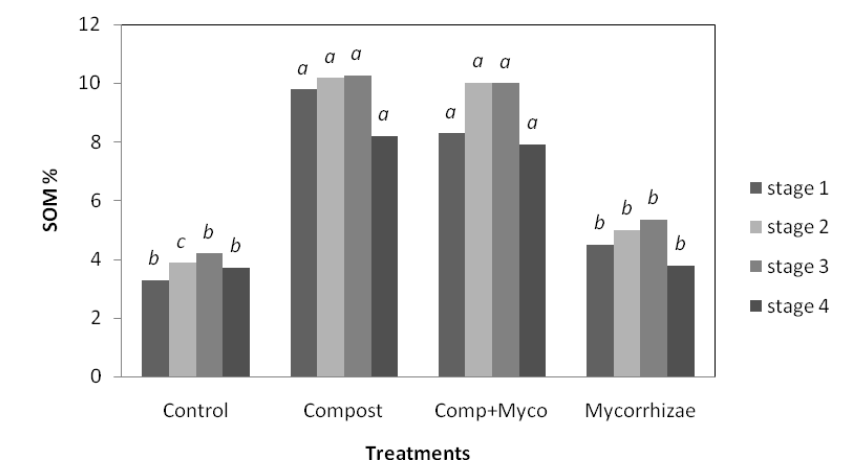

Stage 1 = Rainy season; Stage 2= Rainy season; Stage 3=Dry season; Stage $4=$ Rainy season

Means appear with same letter are not significant at $\mathrm{p}<0.05$ Fig. 5. Status of SOM\% among the treatments at four different stages of sampling in $0.2 \mathrm{~m}$ depth.

The soil organic matter content in a soil expresses the relationship between the sources of organic materials and the decomposing factors (soil biota) [37]. Soil organic matter (SOM) level in the study area of Horton Plains has not reached upper levels in the range, up to $12 \%$, as expected in tropical moist evergreen forests [38]. In ordinary tropical moist evergreen forests, SOM content varies around 6\% [39]. Relatively low plant nutrient levels in montane forests are not unusual according to past studies (e.g., [40], [41]. For each $1000 \mathrm{~m}$ rise in altitude, there is a $7^{\circ} \mathrm{C}$ drop in temperature [42]. This has a dramatic effect on plant and animal distribution in this ecosystem. With the elevation of about $2524 \mathrm{~m}$, Horton Plains is cold (mean annual temperature 15 $\left.{ }^{\circ} \mathrm{C}\right)$ and contains a very specific vegetation which is much more sensitive to the changes in the environment than normal tropical forests [43]. Under the prevailing conditions in the montane environment- low sunlight, low temperature, shallow soil depth and so on, production of SOM is weaker in the Horton Plains than in an ordinary tropical forest [44]. Lower levels and reduced rates of decomposition of SOM in 
Horton Plains may have resulted in relatively lower N, P, K, $\mathrm{Ca}$ and $\mathrm{Mg}$ levels in the soils since the source of those nutrient elements to the soil is mainly from SOM.

The SOM content was significantly different among the treatments in stage $1(p=<0.001)$, stage $2(p=<0.001)$, stage $3(p=<0.001)$ and stage $4(<0.001)$ at the $0.20 \mathrm{~m}$ depth (Fig. $5)$. The soils treated with compost and compost with mycorrhizae mixture showed higher SOM contents. Treatments with mycorrhizae only and the control showed the lowest SOM levels at all four stages.

Across different stages at $0.2 \mathrm{~m}$ depth, the highest SOM content was exhibited in the stage -3 (dry season) but the statistical analysis under $\alpha$ level of 0.05 , was not significant. Over-night frost is fairly common during the period from January to March, and the stage -3 sampling was done within a dry period for Horton Plains which showed the lowest mean temperature of around $6^{\circ} \mathrm{C}$ [3]. Plant debris gets decomposed at very low rates and further decomposition of SOM is restricted during this period due to low soil temperature and lower soil $\mathrm{pH}$ levels which also enhance this situation. Therefore, it may be possible to expect relatively higher SOM levels in stage -3 sampling compared to the other stages. Fluctuation of SOM levels in the area may be linked with temperature, rainfall, soil depth and addition of organic debris from the aggressively growing undercover vegetation such as Strobilanthus spp.

The function of SOM springs from its effects on soil structural stability (its action as a bonding agent between primary and secondary mineral particles leads to enhanced amount, size and stability of aggregates) and soil water retention (as a water adsorbing agent, it enhances water acceptance and availability) and, hence, on infiltration and percolation [45]. At the same time, SOM controls soil nutrients that affect biodiversity and system productivity. Soil structural stability is influenced by the type of organic matter, as well as its amount. Therefore, in some cases, high SOM content is not accompanied by high structural stability. Some fungi exude oxalic acid, which enhances dispersion and breakdown of aggregates [46]. Humic substances are the components of SOM which play the key role in detoxifying the soil from pollutants such as $\mathrm{Pb}$ and $\mathrm{Cd}$ residues of agro-chemicals from surrounding areas [47]. Unsatisfactory levels of SOM exhibit the poor activity of humic substances and resultant soil pollution. Even a milder form of soil contamination in the Horton Plains cannot be afforded since the montane vegetation is highly sensitive to even minute changes in the environment. This condition may also have triggered forest dieback in this specific forest.

\section{E. Death Rate of Syzygium Rotundifolium Saplings}

It was clearly evident that the addition of standard compost and mycorrhizae has significantly controlled the death of Syzygium rotundifolium saplings. Treatment effect on the death of saplings was significant $(p=<0.001)$ since the control clearly showed the highest death rate (Table III). The standard compost consists of humic acid and fulvic acid formed during the microbial decomposition of organic materials. These specific molecules, known as humic substances, possess extraordinary capability of immobilizing soil contaminants such as $\mathrm{Pb}$ and $\mathrm{Cd}$. Additionally, dozens of fractions in compost help the plants to withstand stressful conditions such as drought, nutrient imbalances, acidity and so on [27]. In addition, standard compost is a good reservoir of all forms of essential plant nutrients and growth factors of plants [27].

TABLE III: VARIATION OF DEATH RATE OF SYZYGIUM ROTUNDIFOLIUM SAPLINGS

\begin{tabular}{|l|c|c|c|c|l|}
\hline & Treatment & Control & $\begin{array}{l}\text { Compo } \\
\text { st }\end{array}$ & $\begin{array}{l}\text { Comp+ } \\
\text { Myco }\end{array}$ & $\begin{array}{l}\text { Mycorr } \\
\text { hizae }\end{array}$ \\
\hline $\begin{array}{l}\text { Death } \\
\text { rate }(\%)\end{array}$ & Mean & 46.67 & 15.83 & 17.67 & 31.67 \\
\hline & & $(8.43)$ & $(0.40)$ & $(0.92)$ & $(3.07)$ \\
\hline
\end{tabular}

Standard error for the respective mean is given within brackets.

Mycorrhizae, on the other hand, act as a remarkable symbiotic mechanism for the plants to survive under stressful conditions such as droughts, nutrient deficiency, soil contaminants such as $\mathrm{Pb}$ and $\mathrm{Cd}$ [20]. Mycorrhiza helps the plants to recover the damages done by the toxic substances entered into plant bodies such as $\mathrm{Pb}$ and $\mathrm{Cd}$ [48]. Some researchers have indicated the increased absorption of heavy metals with the mycorrhizae association though the importance of this symbiotic association for plants to face stressful conditions [48].

Thus, it could be argued that treating the Syzygium rotundifolium samplings with standard compost and mycorrhizae until they become grownup trees might help to fill the gaps caused by the dieback in the forest.

\section{F. Lead in the Soil and Dieback of Plants}

The relationship between $\mathrm{Pb}$ concentration and the death rate of Syzygium rotundifolium saplings was significant ( $p=$ $<0.001)$ while the correlation showed the death rate of saplings has been largely affected by the $\mathrm{Pb}$ concentration in the soil (Fig. 6). Therefore, the death rate of the saplings used for the experiment has appeared to be increased with the increasing availability of $\mathrm{Pb}$ in the soil. Results further revealed that the crucial level of $\mathrm{Pb}$ in relation to the survival of Syzygium rotundifolium saplings was around 60ppm in the Horton Plains soil, beyond this level, even a slight increase of available $\mathrm{Pb}$ in the soil above this crucial level may impose severe damages on plant's metabolism leading to dieback [24].

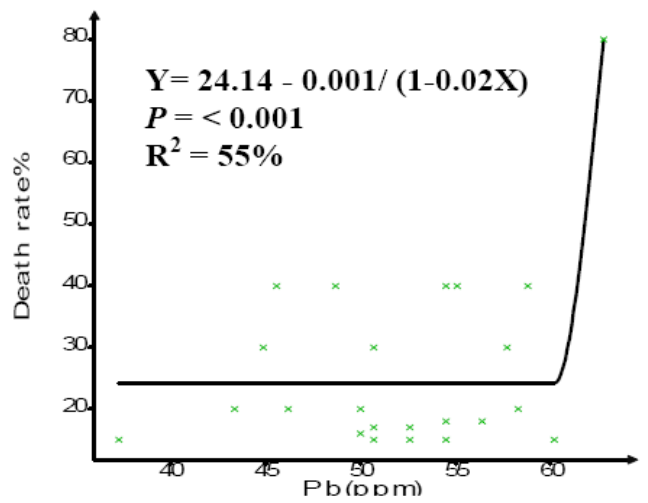

Fig. 6. $\mathrm{Pb}$ concentrations in the soil Vs Death rate of saplings.

\section{G. Cadmium in the Soil and Dieback of Plants}

Death rate of the saplings (Syzygium rotundifolium) used for the experiment appeared to be increased with the increase 
of $\mathrm{Cd}$ availability in the soil. There is a tendency ( $p=0.08$; significant at $\alpha=10 \%$ ) to have a positive linear relationship between the available $\mathrm{Cd}$ in the soil and the death rate of saplings (Fig. 7). It has been proven that the heavy metal $\mathrm{Cd}$ has disturbing effect on some crucial metabolic functions of plants and breaking down of them may have resulted in this relationship [49].

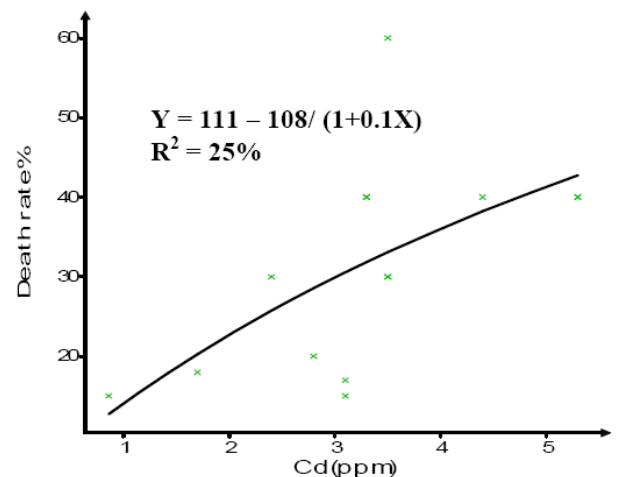

Fig. 7. Cd concentrations in the soil Vs Death rate of saplings.

\section{H. Lead Concentrations in Soils Vs Pb Concentrations in Foliage Parts}

Results showed that the increase of $\mathrm{Pb}$ level in the soil results in an increase of the level of $\mathrm{Pb}$ in leaves of Syzygium rotundifolium saplings. The relationship between soil $\mathrm{Pb}$ level and the $\mathrm{Pb}$ in leaves was significant $(p=0.01)$ and the nature of the relationship is linear - by -linear (hyperbola) (Fig. 8).

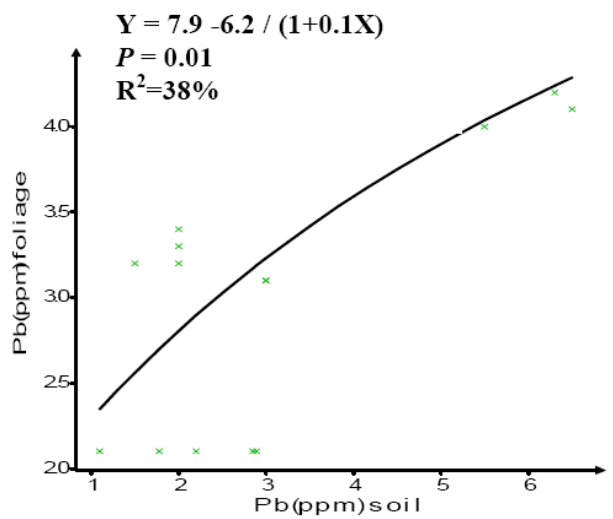

Fig. 8. $\mathrm{Pb}$ concentrations in soils $\mathrm{Vs} \mathrm{Pb}$ concentrations in foliage parts.

\section{Cd Concentrations in Soils Vs Cd Concentrations in Foliage Part}

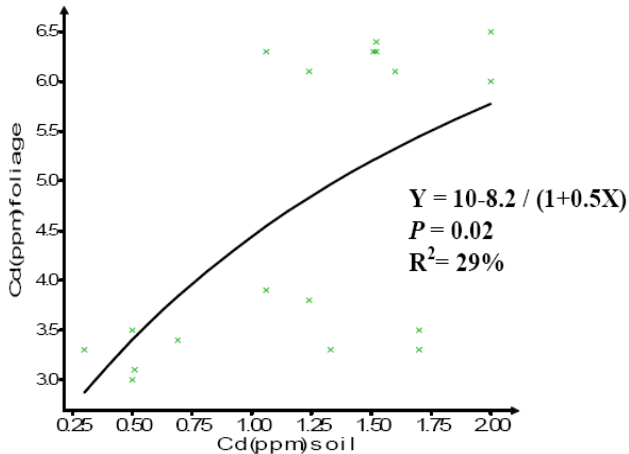

Fig. 9. Cd concentrations in soils Vs Cd concentrations in foliage parts (dry period).
Cadmium concentration in soil used for the experiment appears to have increased $\mathrm{Cd}$ in the leaves. The relationship between the available $\mathrm{Cd}$ in the soil and the $\mathrm{Cd}$ in leaves were statistically significant $(p=0.02)$ and showed a liner increment $\mathrm{Cd}$ in the leaves of sapling with soil Cd levels (Fig. 9).

\section{J. Soil Organic Matter Content in the Soil and Dieback of Plants}

Results showed that the increase of SOM level helps to reduce the death rate of saplings. The relationship between SOM level and the death rate of the saplings (Syzygium rotundifolium) was significant ( $p=0.05)$. The nature of the relationship seems to be linear-by-linear and it further indicates that by maintaining SOM level somewhere above $4 \%$, the death rate of the saplings could be reduced significantly (see Fig. 10). Again, the presence of humic acid and fulvic acid molecules in SOM may have contributed to immobilize toxic metals such as $\mathrm{Pb}$ and $\mathrm{Cd}$ in the soil.

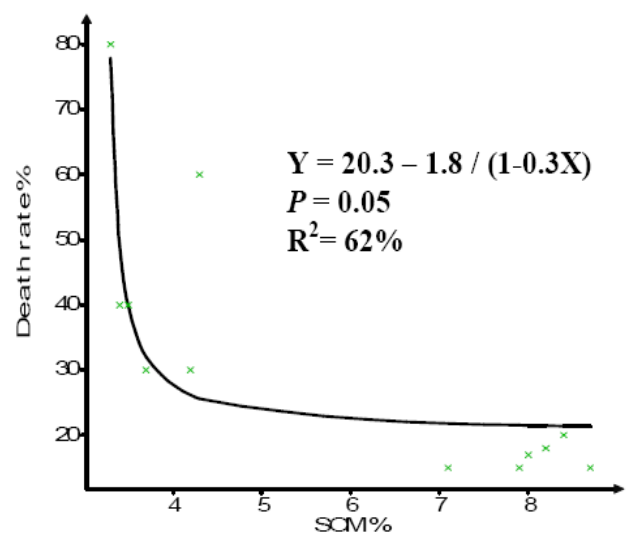

Fig. 10. Soil organic matter content in the soil vs Death rate of saplings.

\section{CONCLUSION}

The level of soil contamination in the dieback areas of the forest with $\mathrm{Pb}$ and $\mathrm{Cd}$ appears to have exceeded the tolerable levels of affected forest tree species. Treatment of the contaminated forest soil with standard compost and montane mycorrhizae is effective in saving saplings of Syzygium rotundifolium from prevalent soil toxicity in the forest. Soluble soil $\mathrm{Pb}$ concentration of $\approx 60 \mathrm{ppm}$ in the study area appears to be a threshold level for the Syzygium rotundifolium saplings, beyond which, an abrupt rise of death rate is observed. Coinciding with the survival of Syzygium rotundifolium saplings with $\mathrm{Pb}$ toxicity, $\mathrm{SOM} \%$ of $\approx 4$ also appears to be a threshold level of SOM in relation to the death rate of the saplings. Successful regeneration programs in the forest should be based on the maintenance of SOM level above the threshold to reduce the death rate of Syzygium rotundifolium saplings in the dieback area.

\section{ACKNOWLEDGEMENT}

This experiment was conducted with the financial support of the Department of Wildlife Conservation and Sabaragamuwa University of Sri Lanka. We are also indebted to the Park Warden and the rest of the staff at Horton Plains National Park for their unquestionable support given throughout the study. Our very special gratitude should 
go to the Rubber Research Institute of Sri Lanka for helping us to complete classy laboratory analysis related to the research.

\section{REFERENCES}

[1] W. R. H. Perera, "Thotupolakanda - an environmental disaster?" Sri Lanka Forester, vol. 13, pp. 53-55, 1978.

[2] W. L. Werner, "The upper montane forests of Sri Lanka," The Sri Lanka Forester, vol. 15, pp. 119-135, 1982.

[3] N. K. B. Adikaram, K. B. Ranawana, and A. Weerasuriya, "Forest dieback in the Horton plains national park," Sri Lanka Protected Areas Management and Wildlife Conservation Project, Department of Wild Life Conservation, Ministry of Environment and Natural Resourses, Colombo, 2006, p. 8

[4] K. B. Ranawana, R. L. R. Chandrajith, and N. K. B. Adikaram, "Follow up study of forest die-back in Horton Plains National Park," in Proc. Wild Life Research Symposium, Protected Area Management and Wide Life Conservation Project, 2007.

[5] T. C. Whitmore, Tropical Rain Forests of the Far East, Claredon Press, Oxford, 1984.

[6] R. A. Wijewansa, "Horton Plains: a plea for preservation," Loris, vol. 16, pp. 188-191, 1983.

[7] S. Ratnayeke and S. Balasubramaniam, "The structure and floristic composition of the montane forest in the Horton Plains, Sri Lanka," Institute of Fundamental Studies, Colombo, Sri Lanka, p. 14, 1989.

[8] S. Balasubramaniam, S. A. Rathnayake, and R. White, "The montane forests of the Horton Plains nature reserve," in Proc. International and Interdisciplinary Symposium Ecology and Landscape Management in Sri Lanka, 1993, pp. 95-108.

[9] M. Peech, "Soil pH: Glass electrode method," in Methods of Soil Analysis Part 2, C. A. Black et al., Ed. Am. Soc. of Agron. Inc., Madison, Wisc, USA, 1983, pp. 910-918.

[10] C. A. Bower and L. V. Wilcox, "Soluble salts," in Methods of Soil Analysis Part 2, C. A. Black et al., Ed. Am. Soc. of Agron. Inc., Madison, Wisc, USA, 1983, pp. 933-936.

[11] USEPA, "Acid digestion of sediments, sludges and soils," Method 3050B, 1996

[12] E. Dale and H. Norman, "Atomic absorption and flame emission spectrometry," in Methods of Soil Analysis, Part 2, 2nd ed. A. L. Page et al., Ed. American Society of Agronomy, Inc., Madison, WI, USA, 1982, vol. 9, pp. 13-27.

[13] D. W. Nelson and L. E. Sommers, "Total carbon, organic carbon and organic matter," in Method of Soil Analysis, Part 2, 2nd ed. American Society of Agronomy, Madison, WI, USA, 1982, vol. 9.

[14] H. Bohn, B. MeNeai, and G. O'Connor, Soil Chemistry, 2nd ed., John Wiley and Sons, New York, 1986.

[15] J. A. Ranasinghe, A. M. Barnett, K. C. Schiff, D. E. Montagne, C. Brantley, C. Beegan, D. B. Cadien, C. Cash, G. B. Deets, D. R. Diener, T. K. Mikel, R. W. Smith, R. G. Velarde, S. D. Watts, and S. B. Weisberg, Southern California Bight 2003 Regional Monitoring Program: III Benthic Macro Fauna, Southern California Coastal Water Research Project Authority, Costa Mesa, CA, 2007.

[16] H. F. Stroo, T. M. Klein, and M. Alexander, "Heterotrophic nitrification in an acid forest soil and by an acid-tolerant fungus," Applied and Environmental Microbiology, vol. 52, pp. 1107-1111, 1986.

[17] E. D. Vance and N. M. Nadkarni, "Microbial biomass and activity in canopy organic matter and the forest floor of a tropical cloud forest," Soil Biology and Biochemistry, vol. 22, pp. 677-684, 1990.

[18] T. M. McCalla, "Influence of some microbial groups on stabilizing soil structure against falling water drops," in Proc. American Soil Science Society, 1946, vol. 11, pp. 260-263.

[19] H. Marschner, "Mechanisms of adaptation of plants to acid soils," in Proc. the Second International Symposium on Plant-Soil Interactions at Low pH, Beckley, West Virginia, USA, 1991, pp. 683-702.

[20] R. B. Clark, "Arbuscular mycorrhizal adaptation, spore germination, root colonization, and host plant growth and mineral acquisition at low pH," Plant and Soil, vol. 19, pp. 15-22, 1997.

[21] L. Keikens, Heavy Metals in Soils, John Willey and Sons, New York, 1990, p. 279.

[22] R. H. Bray and L. T. Kurtz, "Determination of total, organic and available forms of phosphorus in soils," Soil Science, vol. 59, pp. 39-45, 1945.

[23] A. Kloke, "Orientierungsdaten für tolerierbare gesamtgehalte einiger elemente in kulturboden mitt," VDLUFA. H., vol. 1-3, pp. 9-11, 1980.
[24] A. B. Pahlsson, "Toxicity of heavy metals, $(\mathrm{Zn}, \mathrm{Cu}, \mathrm{Cd}, \mathrm{Pb})$ to Vascular Plants," Water, Air and Soil Pollution, vol. 47, pp. 287-319, 1989.

[25] V. M. Goldschmidt, "The principles of distribution of chemical elements in minerals and rocks," Journal of the Chemical Society. vol. 4, pp. 655-673, 1937.

[26] C. B. Dissanayake, J. M. Niwas, and S. V. R. Weerasooriya, "Heavy metal pollution of the mid-canal of Kandy: an environmental case study from Sri Lanka," Environmental Research, vol. 42, no. 1, pp. 24-35, 1987.

[27] I. Weissenhorn, C. Leyval, and J. Berthelin, "Bioavailability of heavy metals and abundance of arbuscular mycorrhizal in a soil polluted by atmospheric deposition from a smelter," Biology and Fertility of Soils, vol. 19 , pp. 22-28, 1995.

[28] O. A. Illeperuma, "Kandy air most polluted," Daily News, 13 July, 2010.

[29] T. Berg, O. Røyset, E. Steinnes, and M. Vadset, "Atmospheric trace element deposition: Principal component analysis of ICP-MS data from moss samples," Environment Pollution, vol. 88, pp. 67-77, 1995.

[30] M. F. Billett, E. A. Fitzpatrick, and M. S. Cresser, "Long term changes in the $\mathrm{Cu}, \mathrm{Pb}$ and $\mathrm{Zn}$ content of forest soil organic horizons from North - East Scotland," Water, Air and Soil Pollution, vol. 59, pp. 179-191, 1991.

[31] T. G. Siccama, W. H. Smith, and D. L. Mader, "Changes in lead, zinc and copper, dry weight and organic matter content of the forest floor of white pine stands in central Massachusetts over 16 years," Environmental Science and Technology, vol. 14, pp. 54-56, 1980.

[32] T. Rudrappa, K. J. Czymmek, P. W. Pare, and H. P. Bais, "Root secreted malic acid recruits beneficial soil bacteria," Plant Physiology, vol. 148, pp. 1547-1556, 2008

[33] M. J. Harrison, "The arbuscular mycorrhizal symbiosis: An underground association," Trends in Plant Science, vol. 2, pp. 54-59, 1997.

[34] J. Friedland, R. Gregory, K. Kilrenlampi, and A. H. Johnson, "Zinc, $\mathrm{Cu}, \mathrm{Ni}$ and $\mathrm{Cd}$ in the forest floor in the northeastern United States," Water, Air and Soil Pollution, vol. 29, pp. 233-243, 1986.

[35] W. R. Jackson, Humic, Fulvic, and Microbial Balance: Organic Soil Conditioning, Evergreen, CO: Jackson Research Center, 1993.

[36] F. G. Viets Jr., "Micronutrient availability, chemistry and availability of micronutrients in soils," Journal of Agricultural and Food Chemistry, vol. 10, no. 3, pp. 174-178, 1962.

[37] D. J. Greenland and P. H. Nye, "Increase in the carbon and Nitrogen contents of tropical soils under natural fallows," Journal of Soil Science, vol. 10, pp. 284-299, 1959.

[38] P. L. Weaver, E. Medina, D. Pool, K. Dugger, J. Gonzales, and E. Cuevas, "Ecological observations in the dwarf cloud forest of the Luquillo mountains in Puerto Rico," Biotropica, vol. 10, pp. 278-291, 1986.

[39] J. Six and J. D. Jastrow, "Soil organic matter turnover," in Encyclopedia of Soil Science, R. Lal, Ed. Boca Raton, FL, 2002, pp. 936-942.

[40] P. J. Grubb and P. J. Edwards, "Studies of mineral cycling in a montane rain forest in New Guinea. III, the distribution of mineral elements in the above ground material," Journal of Ecology, vol. 70, pp. 623-48, 1982.

[41] D. Mueller-Dombois, P. M. Vitousek, and K.W. Bridges, "Canopy dieback and ecosystem processes in Pacific forests: a progress report and research proposal," Hawaii Botanical Science, vol. 44, p. 100, 1984.

[42] A. Kaplan, M. A. Cane, Y. Kushnir, A. C. Clement, M. B. Blumenthal, and B. Rajagopalan, "Analyses of global sea surface temperature 1856-1991," Journal of Geophysical Research-Oceans, vol. 103, no. 9 , pp. 18567-18589, 1998.

[43] L. L. Loope and T. W. Giambelluca, "Vulnerability of Island tropical montane cloud forests to climate change, with Special Reference to East Maui, Hawaii," Climatic Change, vol. 39, pp. 503-517, 1998.

[44] P. J. Edwards and P. J. Grubb, "Studies of mineral cycling in a montane rain forest in New Guinea, I. The distribution of organic matter in the vegetation and soil," Journal of Ecology, vol. 65, pp. 943-969, 1977.

[45] P. Dutartre, F. Bartoli, F. Andreux, J. M. Portal, and A. Ange, "Influence of content and nature of organic matter on the structure of some sandy soils from West Africa," Geoderma, vol. 56, pp. 459-478, 1993.

[46] R. P. Voroney, J. A. Van Veen, and E. A. Paul, "Organic carbon dynamics in grassland soils, II. model validation and simulation of the long-term effects of cultivation and rainfall erosion," Canadian Journal of Soil Science, vol. 61, pp. 211-224, 1981.

[47] J. W. Doran, M. Sarrantonio, and M. A. Liebig, "Soil health and sustainability," Advances in Agronomy, vol. 56, pp. 1-5, 1996. 
[48] R. Bradley, A. J. Burt, and D. J. Read, "Mycorrhizal infection and resistance to heavy metal toxicity in Calluna vulgaris," Nature, vol. 292, pp. 335-337, 1981.

[49] W. W. Wenzel, D. C. Adriano, D. E. Salt, and R. Smith, "Phytoremediation: a plant-micro based system," in Remediation of Contaminated Soils, D. C. Adriano, J. M. Bollag, W. T. Frankenberger Jr, and R. C. Sims, Eds. SSSA Spec Monogr, 1999, ch. 37, pp. 457-510.

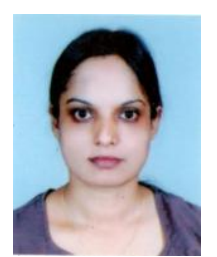

H. K. S. G. Sajanee was born in Sri Lanka on January 30, 1979 and received a B.Sc. degree from Sabaragamuwa University of Sri Lanka, in 2005 with specialization in agriculture and horticulture. Sajanee recieved her master degree of philosophy from the University of Peradeniya, Sri Lanka in 2012 specializing in crop science and her research topic was "Assessing the nutrients imbalance and its impact on forest dieback of Syzygium rotundifolium in Horton Plains".

She is a lecturer at Uva Wellassa University, Sri Lanka, and worked as an assistant lecturer and demonstrator at Sabaragamuwa University of Sri Lanka. Her previous research interest was crop science and soil degradation, with current interest in environmental science.

She has received the Postgraduate Research Award in 2012 from the Sri
Lanka Association for the Advancement of Science (SLAAS), Sri Lanka.

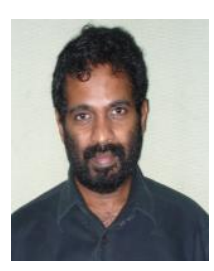

P. I. Yapa was born in Sri Lanka on June 28, 1964 and received a B.Sc. degree from the University of Peradeniya, Sri Lanka, in 1990 with specialization in agriculture and soil science. After the completion of the M.Sc. degree in soil science at the same university in 1996, Yapa earned his doctoral degree from the University of Reading, UK, in 2003 specializing in soil and environmental sciences.

$\mathrm{He}$ is a lecturer at Sabaragamuwa University, Sri Lanka, and worked as a postdoctoral research fellow at Agriculture and Agri-Food Canada. His previous research interest was mitigation of greenhouse gas emission from farmland, with current interest in soil remediation.

Dr. Yapa has received the Postdoctoral Fellowship Awards from National Research and Engineering Council, Canada and Endeavour, Australia. 